\title{
Android Apllication Design for Smart Home Control
}

\author{
Sukandar Sawidin \\ Information Technology Dept \\ Manado State Polytechnic \\ North Sulawesi - Indonesia
}

\author{
Sulastri Eksan \\ Information Technology Dept \\ Manado State Polytechnic \\ North Sulawesi - Indonesia
}

\author{
Ali A. S. Ramschie \\ Electrical Engineering Dept \\ Manado State Polytechnic \\ North Sulawesi - Indonesia
}

\begin{abstract}
Nowadays, controlling electronic devices at home become more easy because in general electronic devices already have integrated with Android smartphone device.

This research aims to create a smart home control system that can facilitate human activities at home such as turning on and off the lights, open and close the door, set the room temperature, maintain home security, open and close the fence gate with Android smartphone as a remote alsoArduino Uno Microcontroller as control system which is using bluetooth as communication media. Testing result shows that this application using Android smartphones can replace the function of switch.

The distance of the android smartphone with the module Buetooth-HC05 to control the electronic devices does not exceed 10 meters. Response time when the android switch is pressed for a distance of 1-5 meters is 0.3 seconds and for a distance of 5-10 meters is 0.5 seconds.
\end{abstract}

\section{General Terms}

Smartphone Android, Bluetooth Electronics

\section{Keywords}

Arduino Uno, Bluetooth HC-05, Sensor Temperature and Laser.

\section{INTRODUCTION}

The increasing of human needs make everyone dependent on technology. Many ways have been doneto fullfilall needs, one of themby applying technology.Everyone can do something indirectly by using technology.Innovation and technology development make electrical devicesat home automatically control by using a microcontroller. $[1,2]$

Smartphone with Bluetooth technologyas a part of the ever evolving mobile technology is a phone that has many features, such as receiving or transmitting data over a wireless connection remotely.[4,6]

It will be Androidbased smarthome control designed to control lighting, electronic devices and home security via smartphone as a new alternative solution for remote controlling. [3,5]

This research aims to create a control system that can enable and disable the electrical devicesat home, using a combination circuit between the microcontroller and the relay as an automatic switch that is connected through a smartphone via a Bluetooth connection. [4]

\section{LITERATURE REVIEW}

\subsection{Android}

Android is a mobile operating system based on Linux thatincludes an operating system, middleware and applications. Android provides an open platform for developers to create their application.
Basic operating system Android is under the GNU General Public License Version 2 (GPLv2). [3,6]

\subsection{Arduino Uno Microcontroller}

Arduino Uno microcontroller is an electronic circuit that is open source, and has hardware and software that is easy to use. Arduino can recognize the surrounding environment through various types of sensors and can control lights, motors, and various other types of actuators. Arduino has many types, including Arduino Mikro, Arduino Uno, Arduino Mega 2560, Arduino Fio, and others. (Www.arduino.cc) [1,3]

\subsection{Bluetooth technology}

Bluetooth is a short-range radio communication system which is intended to replace the cable as a link among devices or between devices and portable electronics. Bluetooth advantages include robustness (good endurance, such as against interference),simple device category, low power and low cost. Bluetooth operates in the $2.4 \mathrm{GHz}$ frequency bandwhich is an unlicensed ISM band (Industrial, Scientific and Medical) with IEE $802.11 \mathrm{~b}$ standard. The usage of hopping frequency to transceiver is for reducing the interference. [3,4]

\subsection{Temperature Sensor}

The temperature sensor uses LM35, where the output of the LM35 can provide an 8-bit output data that states the changing conditions of the ambient temperature. Any temperature changes, there will be changes in the generated output indicates bydifference of voltage result. LM35 as a temperature detection device has the following characteristics:

1. Working on voltage rating $4 \mathrm{~V}$ up to $30 \mathrm{~V}$.

2. Temperature readings range from $-55^{\circ} \mathrm{C}$ up to $150{ }^{\circ} \mathrm{C}$.

3. With a temperature rise of $10^{\circ} \mathrm{C}$ then the output voltage will rise by $10 \mathrm{mV}$.

4. Have drain current less than $60 \mathrm{uA}$.
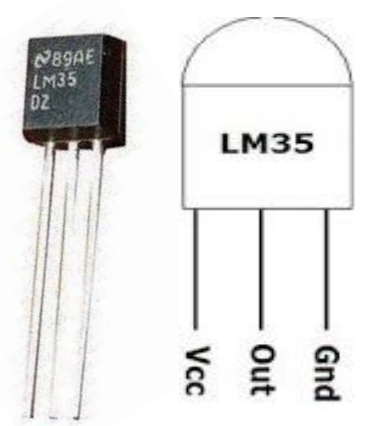

Fig 1. IC LM35

Based on Fig 1, LM35 sensor is a temperature sensor which can detect temperature with a high level of precision. The LM35 sensor has an output voltage that is linearity to celcius temperature. $[2,3]$ 
The LM35 temperature sensor consists of three pin feet. The first pin is Vout PIN serves as the output voltage pin, the second pin is Vs PIN serves as a voltage source pin and the third is GND PIN serves as the ground pin.

The required voltage for the LM35 sensor is $5 \mathrm{~V}$ and has a parameter that every $1{ }^{\circ} \mathrm{C}$ scale increase its output voltage $10 \mathrm{mV}$ so that the following equation is obtained:

$$
\mathrm{V}_{\mathrm{LM} 35}=\text { Temperature } * 10 \mathrm{mV}
$$

For example, device design using LM35 as temperature sensor and the output of ADC produces temperature $20^{\circ} \mathrm{C}$, so when the temperature is $20^{\circ} \mathrm{C}$ the temperature sensor output voltage $\mathrm{LM} 35\left(20^{\circ} \mathrm{C} * 10 \mathrm{mV}\right)=200 \mathrm{mV}=0,2 \mathrm{~V}$. [1,5]

\section{METHODOLOGY}

This research was used design method by making smart home simulation and design of smart home control system to turn on and turn off the lights, open and close the door, set the room temperature, and maintain home security with android smart phone as a controller or remote also use Bluetooth as a communication media. Then perform system testing and evaluation of hardware and software.

\section{RESULT AND DISCUSSION 4.1 System Block Diagram}

In Fig2 the workings of System Block diagram as follows: When Android application activied, system will do the pairing to check if Bluetooth module is active.If Bluetooth module on Arduino Uno microcontroller is active then the Android is ready to give commands, such as selecting the option on android application for turn on lamp1 by shifting switch On and turn off lamp1 with switch Off. That command apply also for lamp2 and lamp3.

If the door switch on is activated (On) then the microcontroller will activate the relay driver and selenoid will open the gate, but if the switch Off is activied then the gate will be closed.

The temperature sensor as an input of the microcontroller detects the temperature of the room, when the room temperature exceeds $300 \mathrm{C}$ then the fan will decreasethe room temperature.If the room temperature does not exceed 300C then the fan is not working (Off).

Laser sensor is used as input of a microcontroller to detect if there are people who pass through the doors, if there are people who pass through the laser sensor then the alarm will sound and the LED indicators also alarms on mobile phones will be active.

If switch on the gate (MP Left) activied then the dc motor will move the gate to the left for open the gate but whentouching the limit switch so DC motor will stop (Off). If the gate switch (MP Right) ON then dc motor will move gate to the rightfor close the gate when touching the limit switch so dc motor will stop (Off).

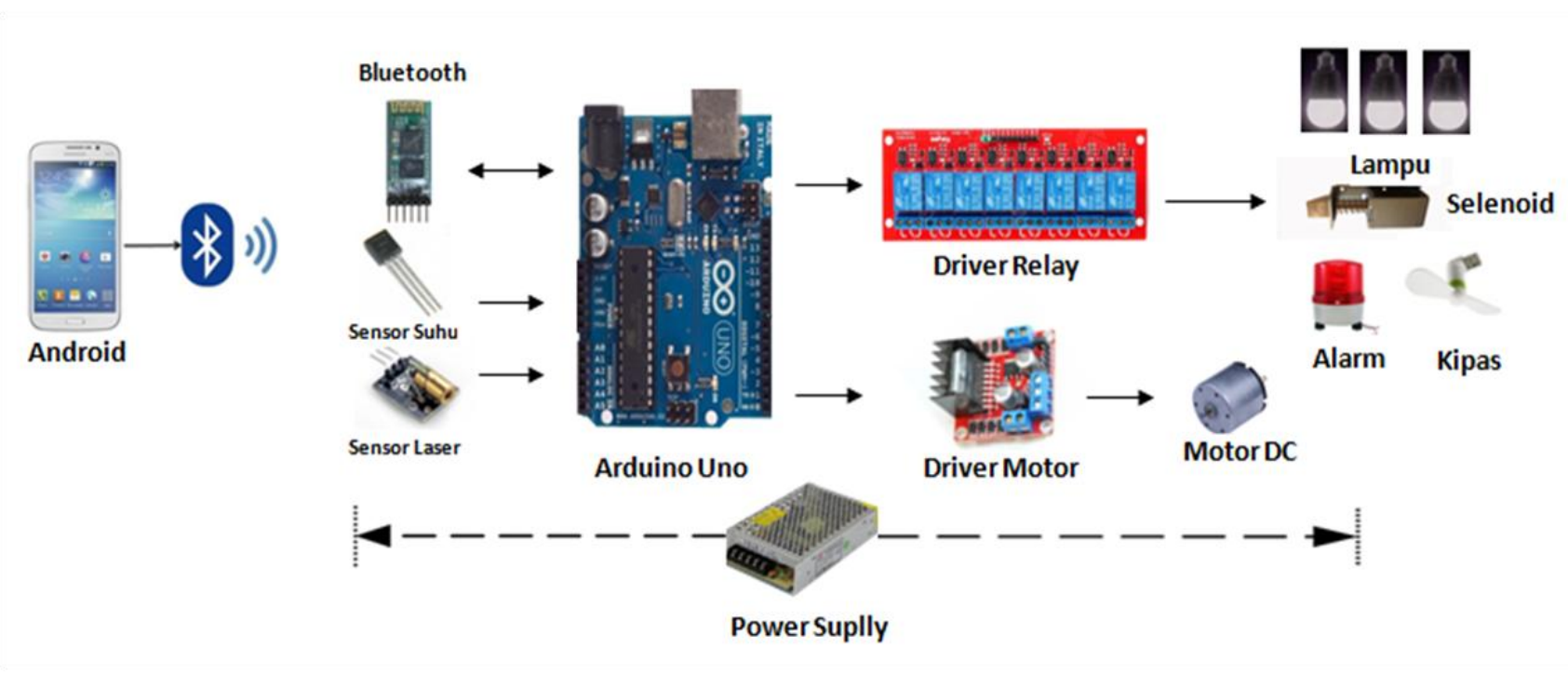

Fig 2. Block Diagram of Smart Home System

Caption:

1. Power supply is usedfor Input / Output device andmicrocontroller Arduino Uno control device with the voltage $5 \mathrm{Vdc}$ and $12 \mathrm{Vdc}$.

2. Smartphone android serves as a media controller for the system control.

3. Controller serves toenable and disable electrical devices

4. Bluetooth serves as a communication media between android smartphone and the controller.

5. Driver Relay serves as a driver to enable and disable electrical devicesat home.

6. Driver Motor serves as a motor drive DC to open and closegate.

\subsection{Smart home Control System Design}

On Fig. 3, If the signal from android smartphone received by Bluetooth module then the microcontroller will process in accordance with the input given so that the desired outputis achieved. Assumed thatthe choice on android application is to turn on the lamp 1 by shifting switch ON lamp 1 then data received in module Bluetooth will process by microcontroller to activate the relay driver and turn on lamp1, otherwiseby shifting the switch Off on android then lamp 1 will turn off. This command apply alsofor the other electronic device. 


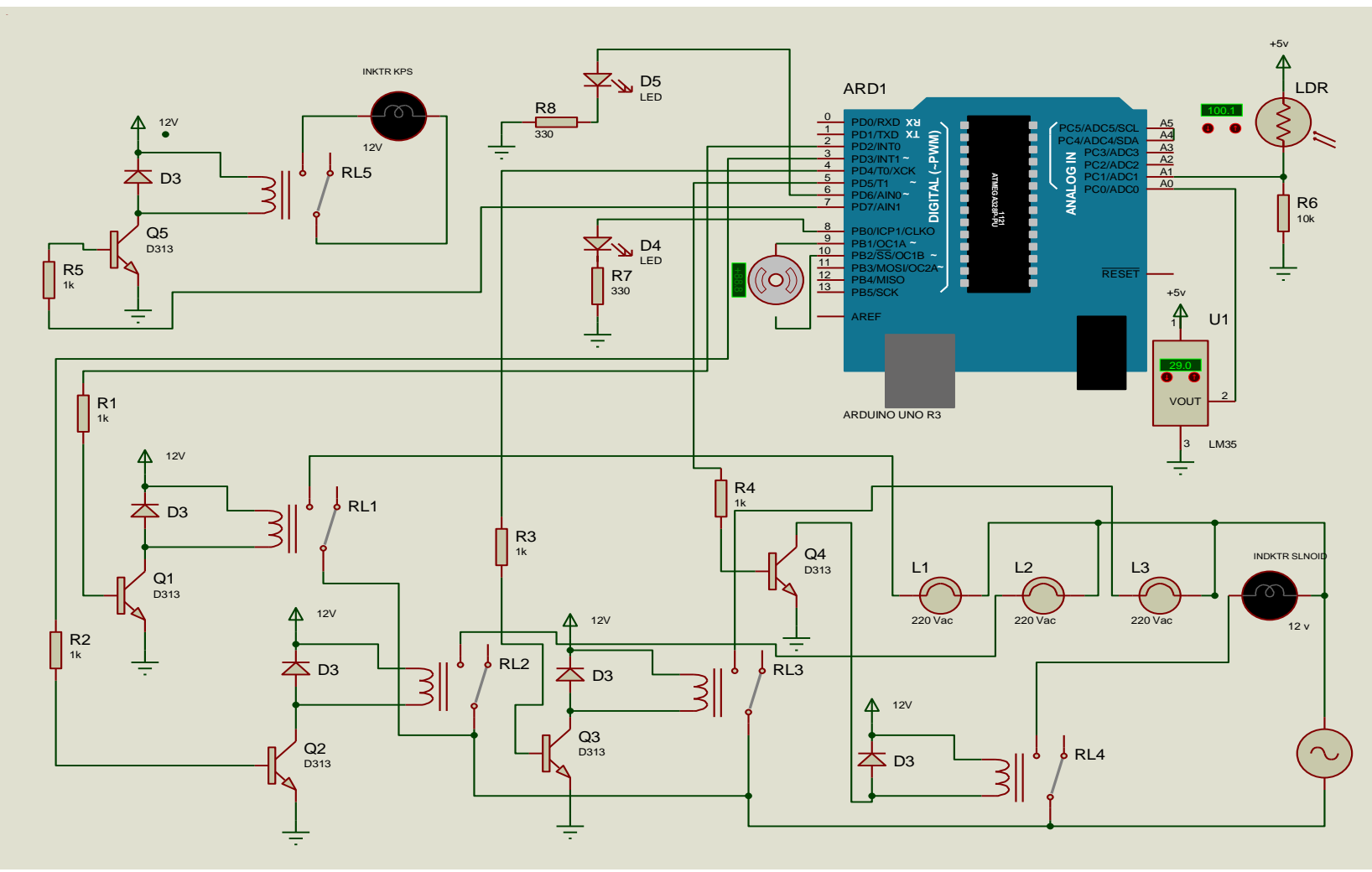

Fig 3. Schematic Design System

\subsection{Android Application Design for Smart Home Control System}

According toFig 4.If the Android Smartphone application and the Bluetooth module on Arduino Microcontrollerare active then the smarthome control system is ready to receive the data.

When lamp 1 switch is On then android send character ' $\mathrm{A}$ ' to microcontroller so driver relay1 active and lamp1 will turn on, but if android send character 'a' (Off) then lamp1 will turn off.

When the android send character 'B' then the lamp2 will turn on, but if the sent character ' $b$ ' lamp2 will turn off.

If the sent character ' $\mathrm{C}$ ' then the lamp3 will turn On, but whenandroid send character ' $c$ ' then lamp3 will turn off.

If the character 'D' is sent then lamp1, lamp2, and lamp3 will turn On, but whenandroid send character ' $\mathrm{d}$ ' then lamp1, lamp2 and lamp3 will turn off.
If the android send character ' $E$ ' then the gate will open, otherwise android send character ' $\mathrm{e}$ ' then gate will be closed.

When the room temperature above $30^{\circ} \mathrm{C}$ is sent the character ' $\mathrm{F}$ ' then the fan will work, when the temperature below $30^{\circ} \mathrm{C}$ sent the fan ' $\mathrm{f}$ ' character does not work. If android send character ' $R$ ' then dc motor will rotate to the right, when the character ' $r$ ' motor dc stop spinning.

If android send character ' $\mathrm{X}$ ' then dc motor will rotate to the left, otherwise the character ' $x$ ' motor dc stop spinning.

If android send character '* L' then Led and Alarm are On. When character '* ${ }^{\prime}$ ' led and alarm will off.

Design of Android Applications is shown in Fig.5. And the design of smarthome program on Arduino Uno microcontroller is shown in Fig 6. 


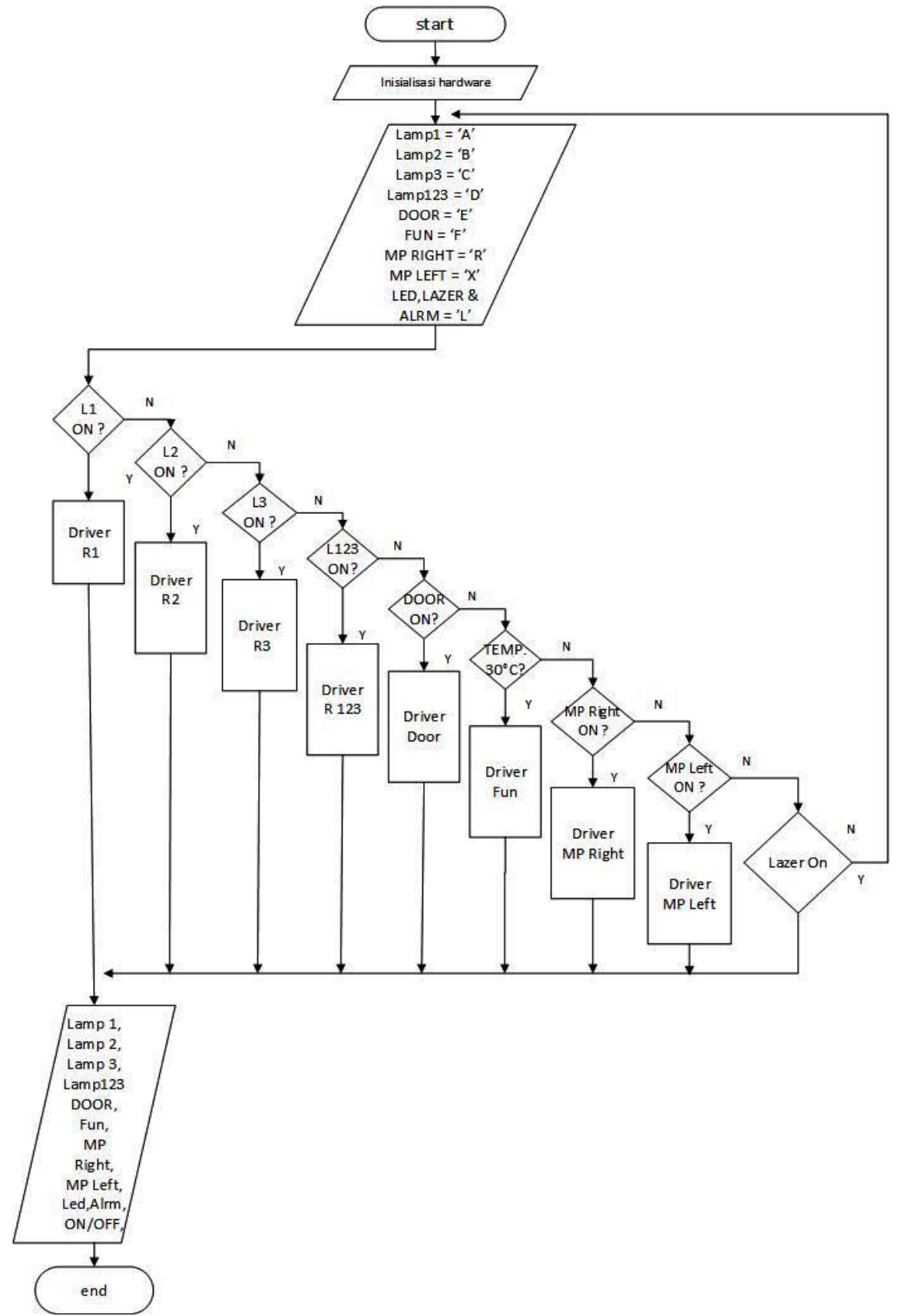

Fig 4. Flowchart System

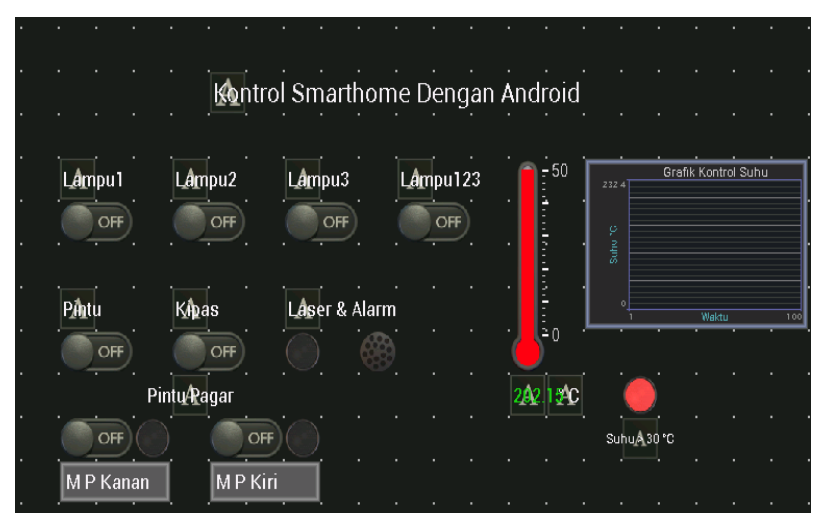

Figure 5. Android Application Design

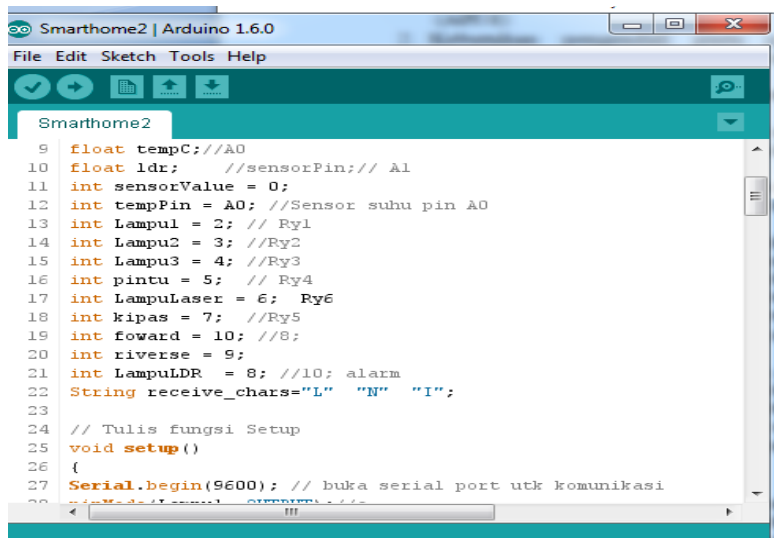

Figure 6. Smart home program design 


\section{SYSTEM TESTING}

\subsection{Android Application Testing and Arduino Program}

Testing for Android application and Arduino program in sending and receiving data is done to find out whether the data sent from Android successfully received and processed by Arduino.

Fig 7 shows how smart home control system testing by creating prototype electronic devices that will be controlled with android smartphone.

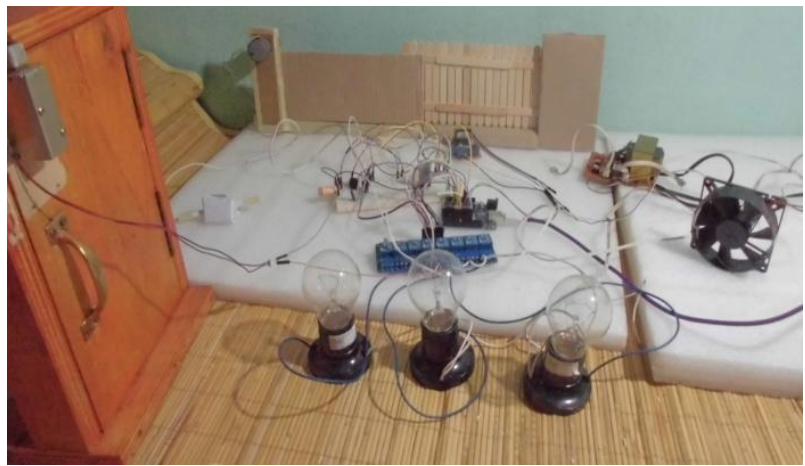

Fig 7. Smart Home Control System

Android smartphone application is activated and bluetooth module to the control system Smart home ready to receive data as shown in Figure 8.

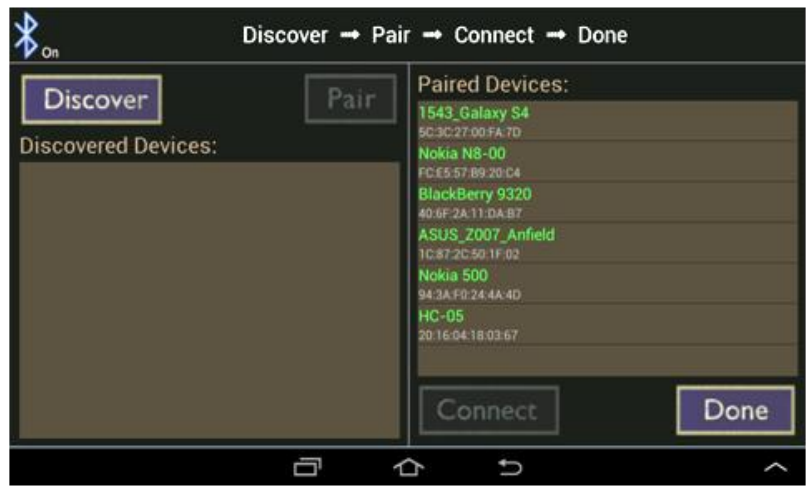

Fig 8. Android Communication With Bluetooth

When Android application is activate then smartphone will be paired toBluetooth deviceand then select the HC-05 (Fig 9).

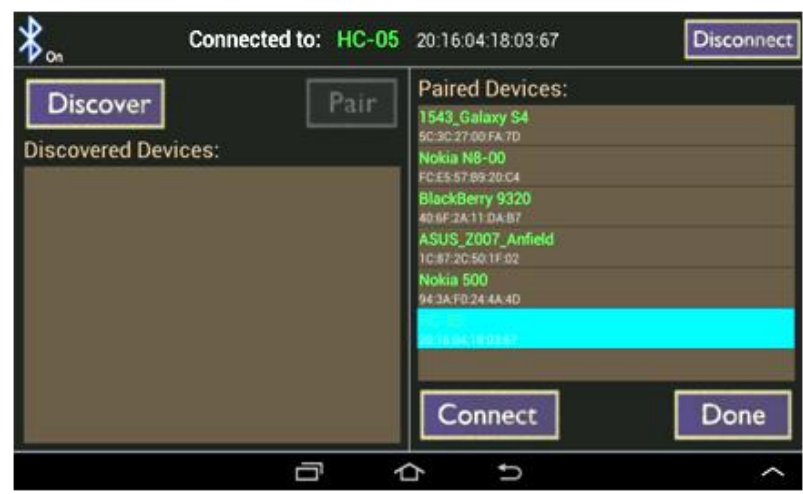

Fig 9. Android Smartphone with Bluetooth HC-05 Is Connected
After communication between Android Smartphone with Bluetooth HC-05 connected then select Done. So the android applications used are ready to use (Figure 10).

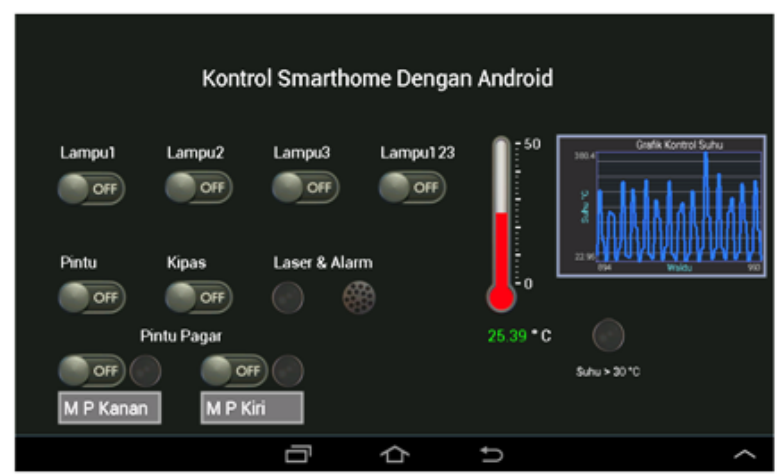

Fig10. Smart Home Control System Using Android Application
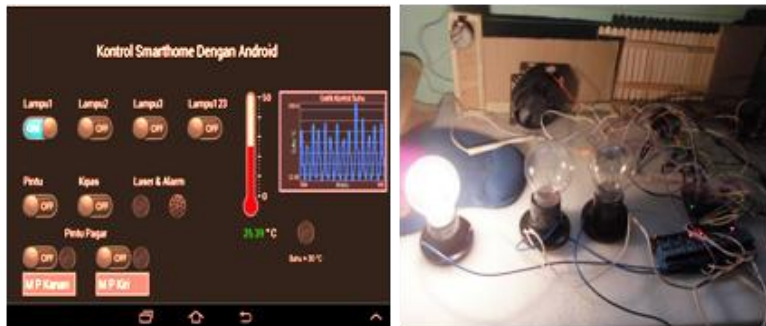

Fig 11. Condition when Lamp 1 is Turn On

In Fig 11. when Switch Onfor lamp1 active then lamp1 will turn on, if switch Off active then lamp1 will turn off.
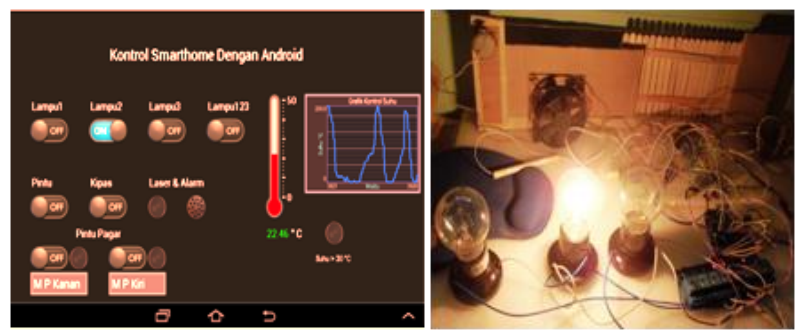

Fig 12. Condition when Lamp 2 is Turn On

In Fig 12. when Switch On for lamp2active then lamp2 will turn on, if switch Off active then lamp2will turn off.
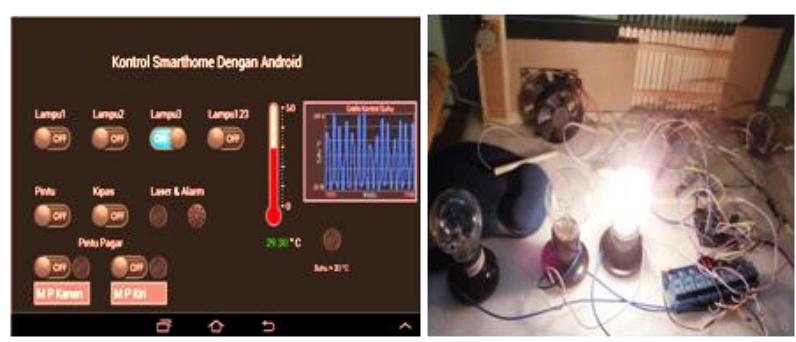

Fig 13. Condition when Lamp 3 is Turn On

In Fig 13, when Switch On for lamp3 active then lamp3 will turn on, if switch Off active then lamp3 will turn off. 

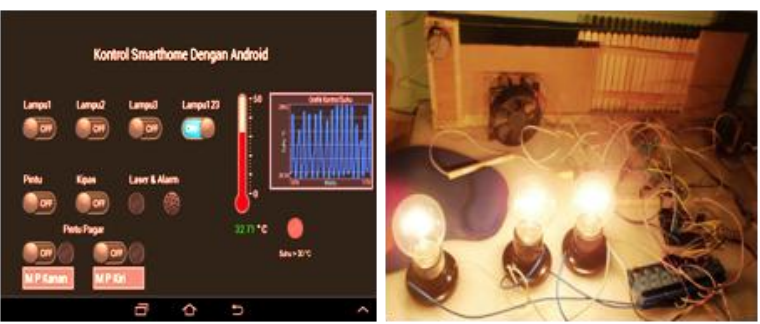

Fig 14. Condition when Lamp123 is Turn On

In Fig 14, when Switch On for lamp123 active then lamp123 will turn on, if switch Off active then lamp123 will turn off.

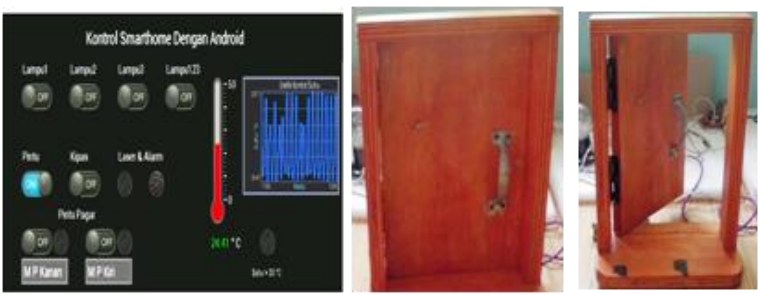

Fig 15. When the Door Button is ON then Door will open

In fig 15, when door button is On then the door will open, otherwise if door button is Off then Door will be closed.

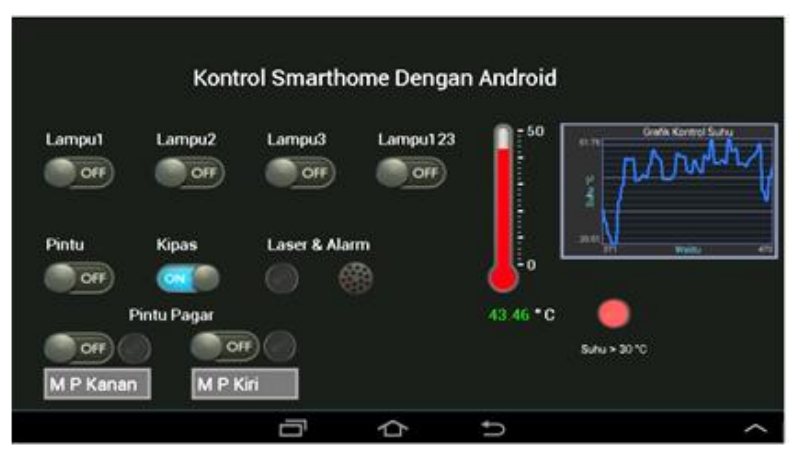

Fig 16. Display for temperature sensor in the room $>30^{\circ} \mathrm{C}$

In fig 16, if the temperature sensor detects room temperature exceeds $30^{\circ} \mathrm{C}$ then the led indicator lights up and fan will active (fig 17) to decrease the room temperature.
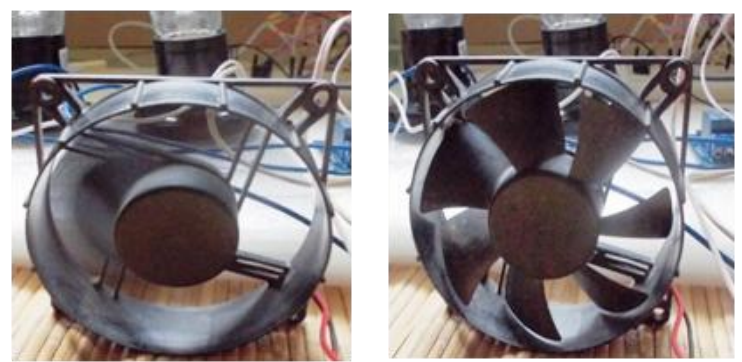

Fig 17. Fan is Active when Room Temperature $>30^{\circ} \mathrm{C}$

When room temperature is less than $30^{\circ} \mathrm{C}$ then led indicator off and fan off.

In fig 18, when the laser sensor is blocked then the led indicator on the android smartphone will light up and the alarm sounds, otherwise if the led indicator off and the alarm does not sound.
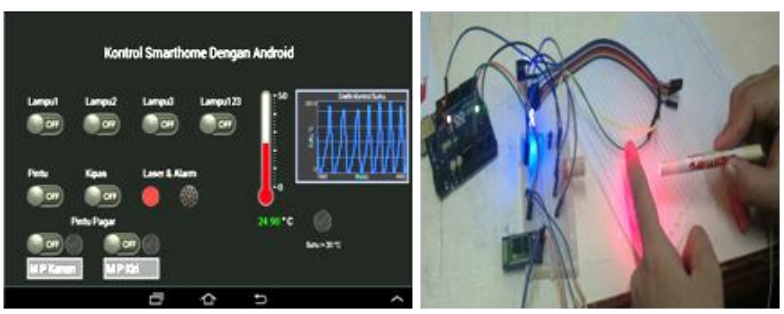

Fig 18. Laser Sensor is Active

In Fig 19, when the Fence Gate button ON then motor will rotate to the right so it closes the gate and will stop when touching the limit switch (fig 20).

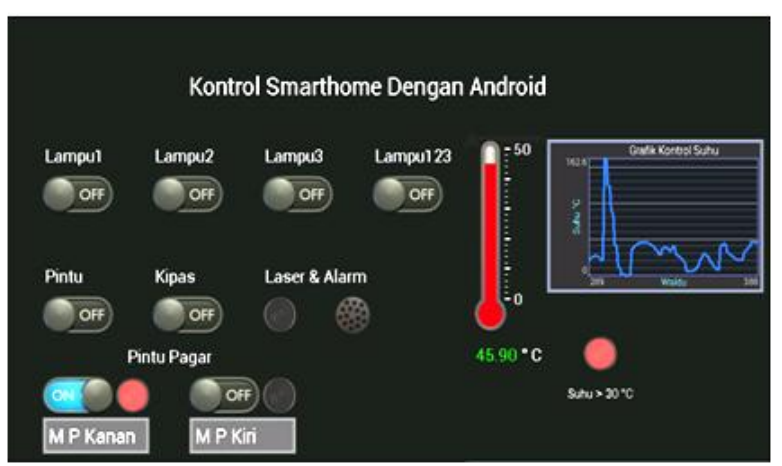

Fig 19. Control to Rotate Right Fence Gate

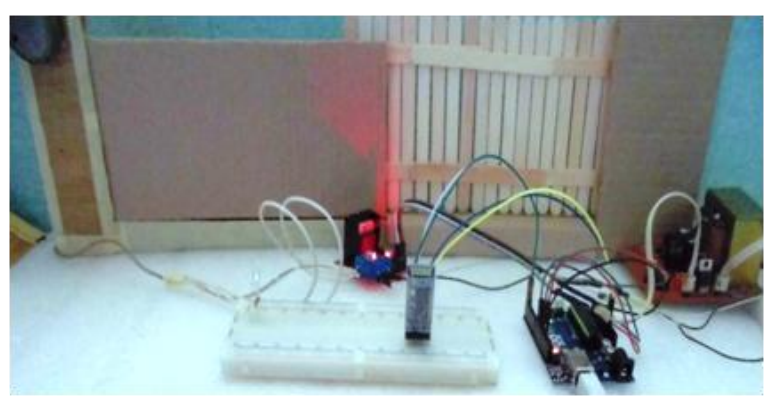

Fig 20. Control to Close the Fence Gate

In Fig 21,when the gate button is ON then motor will rotate to the left so it opens the gate and will stop when touching the limit switch 2. (Fig 22).

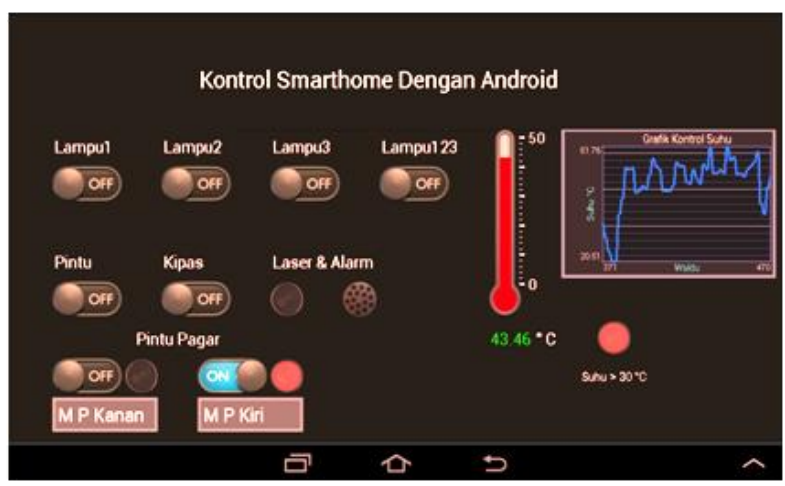

Fig 21.Control to Rotate Left Fence Gate 


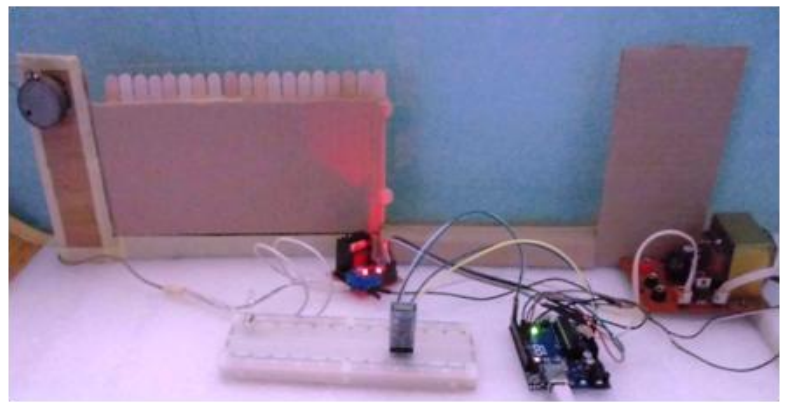

Fig 22. Control to Open Fence Gate

\section{ANALYSIS TEST RESULTS}

\subsection{Testing Distance Between Transmitter (Android) and Receiver (Bluetooth)}

In this testing, each electronic device tested in accordance with the specified distance, which is at a distance of 1-10 meters by pressing the button on/off Android Smartphone Applications for turning on and turning off the electronic deviceat home. When performing the test, the Bluetooth module with Android Smartphone is geared unhindered by any objects. The ability of the Bluetooth module to detect signals from the Android Smartphone is approximately 10 meters (Table 6.1).

Table 6.1. Testing Distance between Android Smartphone and Bluetooth

\begin{tabular}{|c|c|c|c|c|c|c|c|c|}
\hline \multirow{2}{*}{$\begin{array}{c}\text { Distance } \\
(\text { meter) }\end{array}$} & \multicolumn{7}{|c|}{ Electronic Eqipments at Home } \\
\cline { 2 - 10 } & Lamp & Lamp & Lamp & Lamp & door & fan & $\begin{array}{c}\text { MP } \\
\text { Right }\end{array}$ & $\begin{array}{c}\text { MP } \\
\text { Left }\end{array}$ \\
\hline 1 & On & On & On & On & Open & On & Active & Active \\
\hline 2 & On & On & On & On & Open & On & Active & Active \\
\hline 3 & On & On & On & On & Open & On & Active & Active \\
\hline 4 & On & On & On & On & Open & On & Active & Active \\
\hline 5 & On & On & On & On & Open & On & Active & Active \\
\hline 6 & On & On & On & On & Open & On & Active & Active \\
\hline 7 & On & On & On & On & Open & On & Active & Active \\
\hline 8 & On & On & On & On & Open & On & Active & Active \\
\hline 9 & On & On & On & On & Open & On & Active & Active \\
\hline$\geq 10$ & Off & Off & Off & Off & Closed & Off & pasive & pasive \\
\hline
\end{tabular}

From the test results, if the distance Android Smart phone and module Buetooth-HC05 exceed 10 meters is not connected again so that electronic device can't be controlled. Response time when the android switch is pressed for a distance of $1-5$ meters is 0.3 seconds and for a distance of $5-10$ meters is 0.5 seconds.

\subsection{Smart home Control System Analysis}

Android application requirements for Smarthome control system is carried out as follows:

1. Application must running on Smartphone Android.

2. Smarthome control needs: three lamps, fan, temperature sensor, laser sensor, gate, 8 relay drivers, DC motor driver, Led, alarm and Arduino Uno microcontroller as platform to enter program and process the data.
3. Bluetooth moduleto receive the signal string and connect to pin 0 and pin 1 .

4. Three lamps for lighting connected to pin 2, pin 3 and pin 4.

5. The gate for incoming out access is connected to pin 5 .

6. Laser and led sensor / alarm for home security on pins 6 and 8 .

7. Fan to cool the room on pin 7.

8. Motor DC, for moving the gate, located on pin 9 and 10 .

9. The temperature sensor detects the temperature of the room isconnectedto pin $\mathrm{A} 0$ and $\mathrm{LDR}$ connected to pin A1.

Applications installed on Android smartphones in this research using the Samsung GT-P3100. The created application can communicate with smarthome control using Bluetooth connection.

Type of Bluetooth in this system is Bluetooth module HC-05, the application will send data via Bluetooth is subsequently executed by the microcontroller. The microcontroller sends a signal to be able to control the smarthome.

\section{CONCLUSION}

From the results of tests performed, it can be concluded that the smart home android control system using Bluetooth Electronics can control the home electronic devices through the interface on the android smartphone screen and the distance of the android smartphone with the module Buetooth$\mathrm{HC} 05$ can control electronic equipment with a distance of 10 meters.Response time when the android switch is pressed for a distance of 1-5 meters is 0.3 seconds and for a distance of 510 meters is 0.5 seconds.

\section{ACKNOWLEDGMENTS}

The authors would like to thank RISTEK DIKTI, P3M Politeknik Negeri Manado, Team IJCA and all those who can not be mentioned one by one so that this research can be done.

\section{REFERENCES}

[1] Abdul Kadir, Panduan Praktis Mempelajari Aplikasi Mikrokontroler dan Pemogramannya Menggunakan Arduino, Andi Yogyakarta, 2013.

[2] Budhiharto, W.; Interfacing Komputer dan Mikrokontroler; Penerbit Elex Media Komputindo, Jakarta. 2004.

[3] Istiyanto Eko Jazi, Pengantar Elektronika dan Instrumentasi Pendekatan Project Arduino dan Android, CV ANDI OFFSET, Yogyakarta, 2014.

[4] R.A.Ramlee, M.H.Leong, R.S.S. Singh, M.M.Ismail, M.A.Othman, H.A.Sulaiman, M.H.Misran, M.A.Meor Said; Bluetooth Remote Home Automation System Using Android Application, The International Journal of Engineering And Science (IJES), Issue 01, Volume 2, pp.149-153, 2013.

[5] Steven F. Barrett, Atmel AVR Microcontroller Programming And Interfacing, Edisi Pertama, Colorado (USA) : Morgan and Claypool Publishers, 2007.

[6] Safaat, Nazarudin. Android Pemrograman Aplikasi Mobile Smartphone dan Tablet PC Berbasis Android, Jakarta: Informatika, 2011 